\title{
Edukasi Pernikahan Masyarakat Kristen Dalam Pencegahan Perceraian
}

\author{
Mangiring Tua Togatorop ${ }^{1 *}$, Mitra Binariang Lase ${ }^{2}$, Rima Kurnia, Desi Rante Padang ${ }^{3}$, \\ Ester Situmorang, ${ }^{4}$ Megawati Pelle ${ }^{5}$, Elfrida Elena Br Silaban ${ }^{6}$ \\ ${ }_{1,3,4}$ Prodi Teologi, STT REAL Batam \\ 2, 5, ${ }^{6}$ Prodi PAK, STT REAL Batam \\ *togatoroptimo@gmail.com
}

\begin{abstract}
As for the purpose of this study is to provide insights that are truly in accordance with the values of the Christian Faith regarding marriage so that divorce among the Christian community can be prevented. Marriage education is not sufficient only from understanding the customs alone, but it is much more important from the point of view of the Bible or the Teachings of God. Therefore marriage itself is the oldest institution in the world and also the first institution established by Allah on earth. Therefore it is very important for the Christian community to have the correct education about marriage so that divorce as early as possible can be prevented. By using qualitative analysis methods and collecting data sources by digging them from library books, as well as questionnaires that have determined the necessary data in accordance with Christian Community Marriage Education in Divorce Prevention. Based on the results collected, it was made that with the correct Marriage Education that can be applied by every family regarding the marriage they build, Christian Community marriages will be prevented from divorce.
\end{abstract}

Keywords: Education, Marriage and Prevention.

\begin{abstract}
Abstrak
Adapun yang menjadi tujuan dari Penelitian ini untuk memberikan pemahaman-pemahaman yang benar sesuai dengan nilai-nilai Iman Kristen tentang pernikahan sedingga perceraian dikalangan masyarakat Kristen dapat dicegah. Edukasi pernikahan tidak cukup hanya dari pemahaman adat istiadat semata, melainkan jauh lebih penting dilihat dari sudut pandang Alkitab atau Ajaran Tuhan. Karena pernikahan itu sendiri merupakan lembaga tertua di dunia dan juga merupak lembaga pertama yang dibentuk oleh Alllah dibumi. Oleh sebab itu sangat penting sekali bagi masyarakat Kristen untuk memiliki edukasi yang benar tentang pernikahan sehingga perceraian sedini mungkin akan dapat dicegah. Dengan memakai metode analisis kualitatif dan mengumpulkan sumber-sumber data dengan menggalinya dari buku-buku pustaka, serta menyebarkan kuisioner yang sudah ditentukan data-data yang diperlukan yang sesuai dengan Edukasi Pernikahan Masyarakat Kristen Dalam Pencegahan Perceraian. berdasarkan hasil yang sudah dikumpulkan maka dibuatlah kesimpulan bahwa dengan adanya Edukasi Pernikahan yang benar dan dapat dipahami oleh setiap keluarga tentang pernikahan yang mereka bangun, maka pernikahan Masyarakat Kristen akan dapat dicegah dari perceraian.

Kata Kunci: Edukasi, Pernikahan dan Pencegahan.
\end{abstract}

\section{PENDAHULUAN}

Pernikahan adalah lembaga pertama yang dibentuk oleh Allah dan juga merupakan lembaga tertua didunia dari semua lembaga yang ada. Pernikahan tidak hanya dikenal dikalangan masyarakat Kristen saja, melainkan semua agama dan budaya didunia ini mengenal tentang pernikahan. Bagi masyarakat Kristen pernikahan itu tidak ada istilah coba-coba, oleh sebab itu sebelum pasangan memasuki jenjang pernikahan harus memiliki edukasi atau pemahaman yang benar tentang pernikahan, khusunya dari sudut pandang Allah sebagai pembentuk pertama lembaga pernikahan. Edukasi yang benar dalam setiap pasangan suami/istri atau yang akan membangun rumah tangga dengan memberikan konseling pra nikah dan kegiatan kelas keluarga akan dapat mencegah terjadinya perceraian dikemudian hari.

Jutaan pernikahan keluarga Kristen saat ini menghadapi masalah saat ini karena ketidak sanggupan suami-istri untuk bergaul erat, persolan yang paling mendasar salah satunya adalah sikap mementingkan diri sendiri. ${ }^{1}$ pasangan hanya memuaskan dirinya sendiri sehingga gagal memahami (2005): 533 .

${ }^{1}$ Dobson, mames, "Pernikahan Dan Keluarga (Complete Marriage And Family. Gospel Press, Batam" 
dan mengenali kerinduan pasanganya. Lembaga pernikahan akan berhasil apabila suami atau istri tidak memikirkan diri sendiri melainkan lebih memikirkan pasangannya.

Gereja atau gembala sidang yang diberikan wewenang dalam mensahkan sebuah pernikahan harus memiliki beban atau tanggung jawab dalam memberikan edukasi tentang pernikahan bagi setiap jemaat yang akan diberkati. Edukasi tidak hanya diberikan pada saat mau menikah, tetapi harus berkelanjutan dengan cara kegiatan-kegiatan lainnya seperti seminar, reatret dan kelas-kelas keluarga. Dengan memberikan edukasi yang sesuai dengan norma-norma Kristen dan esensi pernikahan itu dari awalnya maka akan dapat mencegah terjadinya perceraian dikalangan masyarakat Kristen. Matius 19:6 berkata: Demikianlah mereka bukan lagi dua, melainkan satu. Karena itu, apa yang telah dipersatukan Allah, tidak boleh diceraikan manusia." Dan juga dalam Markus 10:9 berkata: Karena itu, apa yang telah dipersatukan Allah, tidak boleh diceraikan manusia."

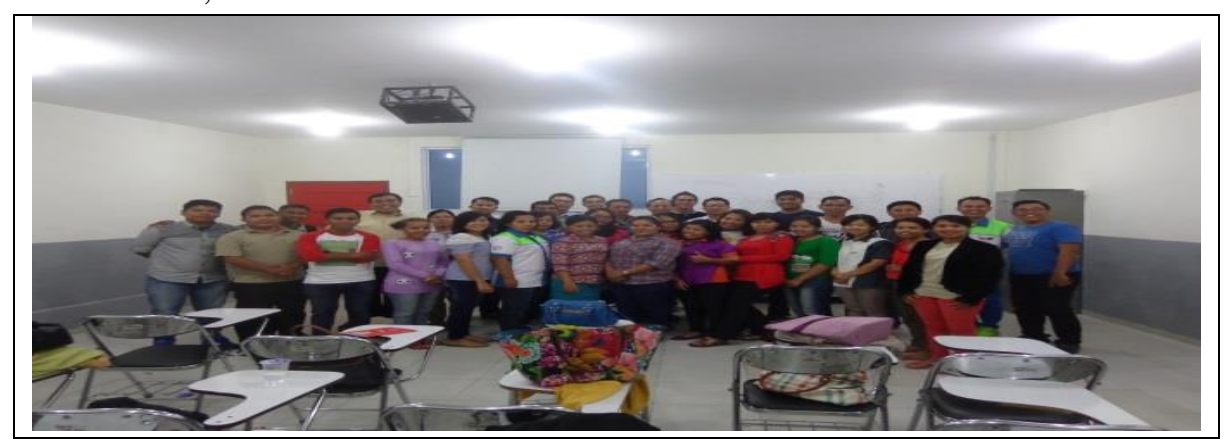

Gambar 1. Edukasi Pernikahan Dalam Pencegahan Perceraian

\section{METODE}

Dalam penelitian ini penulis memakai metode deskripsi kualitatif, atau yang sering disebut metode penelitian naturalistic karena penelitiannya dilakukan pada kondisi yang alamiah (natural setting), ${ }^{2}$ yang mana penelitian ini menganalisa data, dengan mengumpulkan data, mengintepresi data yang ada serta merumuskan kesimpulan yang mengacu pada analisa data. Tujuan daripada penelitian ini adalah menjelaskan fakta, fenomena, kejadian dan keadaan, serta variable yang sedang terjadi pada waktu penelitian dilakukan akan memberikan atau membukakan keadaan yang sesungguhnya. Penelitian Kualitatif memandang objek suatu yang dinamis, dan utuh karena segala aspek dari obyek itu memiliki hubungan antara satu dengan lainnya. Jadi realitas itu merupakan konstruksi atau interprestasi dari pemahaman terhadap semua data yang tampak dilapangan, dan dalam hal penelitian ini hanya menganalisa serta memaparkan data yang berkaitan dengan edukasi pernikahan masyarakat Kristen dalam pencegahan perceraian. Kegiatan Edukasi Pernikahan ini diadakan Pada tanggal 24 Januari 2019 di Gedung Serbaguna GBI My Home Tanjungpinang.

\section{HASIL DAN PEMBAHASAN}

\section{Edukasi Pernikahan Masyarakat Kristen}

Undang-undang Perkawinan No 1 tahun 1974 menyatakan bahwa perkawinan adalah ikatan batin antara seorang pria dengan seorang wanita sebagai suami istri dengan tujuan membentuk keluarga yang bahagia dan kekal berdasarkan ketuhanan Yang Maha Esa. Setiap pasangan selalu mengharapkan pernikahan yang mereka bangun kekal, sampai maut yang memisahkan. Tetapi fakta dilapangan menunjukkan bahwa dikeluarga masyarakat Kristen banyak bercerai karena tidak mengalami keharmonisan dalam keluarga. Beberapa faktor keharmonisan itu tidak ada dalam keluarga, antara lain ekonomi, perselingkuhan, tidak ada keturunan, KDRT dan kurang bertanggung

\footnotetext{
${ }^{2}$ Sugiono, Metode Penelitian Pendidikan, Pendekatan Kuantitatif, Kualitatif, Dan R\& D, Bandung,
} 2009. 
jawab. Badan Kependudukan dan Keluarga Berencana Nasional (BKKBN) Hasto Wardoyo menjelaskan masalah perceraian merupakan persoalan BKKBN untuk melaksanakan perencanaan membangun keluarga sejahatera. ${ }^{3}$ Dalam menghadapi realita yang ada maka pemerintah lewat Menteri Koordinator Pembangunan manusia dan kebudayaan, Muhadjir Effendy, mewacanakan agar calon pengantin yang akan memasuki pernikahan diwajibkan mempunyai sertifikat layak untuk menikah untuk seluruh wilayah Indonesia.

Dalam pencegan terjadinya perceraian di kalangan masyarakat Kristen, sangat diperlukan dilakukan edukasi mengenai sebuah pernikahan sebelum pasangan memasuki jenjang pernikahan, maka setiap calon pengantin mendapatkan sebuah pemahaman tentang pernikahan. Memiliki pengetahuan dari sudut pandang agama, budanya, dan perundang-undangan akan menjadi fondasi bagi pasangan dalam menjalani rumah tangganya.

\section{Tujuan Pernikahan}

Jika sebuah pertanyaan ditujukan kepada pasangan yang mau menikah, bahkan kepada yang sudah menikah, "Apakah tujuan pernikahan?" tentu bercorak ragam jawaban yang diberikan, antara lain: mendapatkan keturunan, penerimaan sosial, Seks, dan membesarkan anak-anak. Kalau berpedoman kepada jawaban yang ada tentu tanpa menikahpun semua itu bisa didapat dan dilakukan.

Dalam menjawab pertanyaan tersebut, perlu dilihat dari sudut pandang iman Kristen, mencari kehendak Tuhan. Dalam Alkitab, dapat dilihat suatu gambaran yang sangat berbeda. Dalam Kitab Kejadian 2:21-24, kitab pertama Alkitab dengan membaca kisah penciptaan manusia, maka kita dapat melihat suatu gagasan yang besar yang dibangun oleh Allah tentang pernikahan. Gagasan pernikahan itu digambarkan bersatunya dua insan yang berbeda jenis kelamin untuk menjalani kehidupan dalam jalan yang terdalam menuju suatu kehidupan baru yang akan memuaskan individu yang berperan dan melayani kehendak Tuhan dalam sikap termulia yang mungkin dilakukan. ${ }^{4}$

\section{Pencegahan Perceraian}

Komunikasi

Pertengkaran, kekerasan dalam rumah tangga, depresi, ketegangan dan ketidakpercayan terhadap pasangannya, seringkali muncul dalam rumah tangga disebabkan buruknya komunikasi dalam setiap pasangan. Setiap pasangan perlu memahami bahwa kunci pernikahan yang harmonis terletak pada komunikasi yang terbuka. Dalam komunikasi yang terbuka akan tercipta keterbukaan terhadap pasangannya. Setiap pasangan keluarga sangat penting melakukan pembicaraan secara transparan dan jujur untuk mencegah terjadinya konflik dalam keluarga. Keluarga yang membangun komunikasi yang baik, akan menjadikan keluarga itu kokoh, dan selalu memiliki suasana menyejukkan karena seisi rumah selalu berlaku baik. ${ }^{5}$ Keluarga yang kokoh selalu dapat mengatasi masalah yang mereka hadapi, dan mereka bersatu, saling mendukung, memiliki loyalitas dan saling mengasihi untuk menyelesaikannya.

\section{Komitmen Dalam Perkawinan}

Kejadian 2: 18 berkata: Tuhan Allah berfirman: "Tidak baik, kalau manusia itu seorang diri saja. Aku akan menjadikan penolong baginya, yang sepadan dengan dia".

\footnotetext{
${ }^{3}$ Repulika.Co.Id. Pentingnya Edukasi Pranikah, Saturday, 30 Nov 2019., n.d.

${ }^{4}$ Gary Chapman, Pernikahan Yang Selalu Anda Dambakan (Tangerang: Gospel pres, 2007).23

${ }^{5}$ Beam Alice Nick, Stinnet, Nancy joe, Fantastic Families (Keluarga Kokoh Dan Bahagia) (Batam centre: Interaksara, 2004).
} 
Inti komitmen pada kesatuan pernikahan adalah didikasi pada hubungan perkawinan. Jika suami istri memenuhi komitmen satu sama lain, mereka sedang meletakkan dasar bagi semua komitmen lainnya yang harus dimiliki keluarga. Pernikahan merupakan jawaban Tuhan bagi kebutuhan manusia yang terdalam, yaitu hidup persekutuan dengan seseorang. Persekutuan ini mencakup seluruh kehidupan, bukan sekedar hubungan fisik, bukan sekedar saling memberi dan menerima dukungan emosional. Akan tetapi merupakan persekutuan menyeluruh dari dua kehidupan dalam tingkat intelektual, sosial, emosional, dan fisik. Persekutuan seperti ini tidak mungkin dapat terwujud tanpa komitmen yang mendalam dan kekal dari Tuhan. Pernikahan bukan kawin kontrak, institusi sosial untuk membesarkan anak-anaknya, dan juga bukan suatu sarana untuk mencapai status sosial. Tujuan tertinggi dari pernikahan adalah persekutuan pada tingkatan yang paling mendalam dan dalam segala bidang, yang pada gilirannya memberikan kemungkinan terbesar atas rasa puas pada pasangannya dan sekaligus memberikan yang terbaik atas kehendak Tuhan bagi kehidupan mereka. ${ }^{6}$ Komitmen menciptakan lingkungan hangat, mencintai, menerima dan di tengah-tengahnya sebuah keluarga tumbuhkembang. Allah melihat saling komitmen diantara pasangan begitu penting dalam keluarga sehingga dengan tegas mengutuk setiap pelanggaran komitmen pernikahan. Dalam firmanNya, ditegaskan bahwa melanggar perjanjian pernikahan itu adalah "melanggar kepercayaan" atau "berkhianat" terhadap pasangannya (Maleakhi 2: 14-16).

\section{Menjadi Satu}

Kejadian 2: 24 berkata: Sebab itu seorang laki-laki akan meninggalkan ayahnya dan ibunya dan bersatu dengan isterinya, sehingga keduanya menjadi satu daging. Injil Matius 19:6 berkata: Demikianlah mereka bukan lagi dua, melainkan satu. Karena itu, apa yang telah dipersatukan Allah, tidak boleh diceraikan manusia.".

Sekedar menikah tidak menjamin kesatuan. Ada perbedaan antara "menjadi satu" dan "kesatuan". Kata "satu" menyatakan kesatuan dari keragaman sebagai lawan dan kesatuan absolud. Dalam ide mengenai kovenan dan penciptaan, dapat ditemukan ketetapan ilahi mengenai pernikahan dalam kovenan dengan Tuhan ${ }^{7}$ Pernikahan merupakan lembaga bentukan Allah yang pertama. suatu ikatan yang tidak bisa dipisahkan oleh apapun, suami dan istri dalam perkawinan Kristen akan menjadi satu kesatuan disemua sektor kehidupan, mejadi satu dalam perencanaan, satu dalam mengurus rumah tangga, satu dalam keuangan, dan satu dalam mendidik anak-anaknya, untuk bisa melakukan semuanya itu suami-istri diperlukan memiliki sikap untuk saling menghargai, saling menerima, saling menguatkan dan saling memberi kasih. Keluarga masyarakat Kristen harus memahami yang menjadi pusat pernikahan itu adalah Allah, Allah yang menjadikan mereka menjadi satu dalam ikatan pernikahan, janji pernikahan bukan untuk pasangannya saja, melainkan perjanjian dengan Tuhan. Perjanjian itu mengikat, dan perjanjian itu baru bisa terputus ketika maut sudah memisahkan. Markus. 10: 6 - 9 berkata: Sebab pada awal dunia, Allah menjadikan mereka laki-laki dan perempuan, sebab itu laki-laki akan meninggalkan ayahnya dan ibunya dan bersatu dengan isterinyasehingga keduanya itu menjadi satu daging. Demikianlah mereka bukan lagi dua, melainkan satu. Karena itu, apa yang telah dipersatukan Allah, tidak boleh diceraikan manusia.". kesatuan itu harus dijaga dan dipertahankan sampai maut yang memisahkan.

\section{Keputusan}

Para sosiolog dan konselor keluarga mengakui bahwa salah satu masalah terbesar dalam pernikahan Kristen adalah proses untuk menentukan keputusan, banyak pasangan muda kehilangan

\footnotetext{
${ }^{6}$ Ibid.

${ }^{7}$ Cornelius Van Til Berkhof, Louis, Foundations Of Christian Education (Surabaya: Momentum, 2008).
} 
kesempatan dan tidak menemukan kata sepakat karena tidak bisa mengambil keputusan. ${ }^{8}$ Jika suamiistri bersepakat dalam satu pola dalam mengambil keputusan, mereka akan dapat menghindari banyak pertengkaran. Saling mengekspresikan dan melengkapi gagasan serta perasaan berkenan untuk mencapai keputusan, dan keputusan yang sudah disetujui suami - istri merupakan keputusan yang terbaik. Jika belum mencapai kata sepakat, dan keputusan harus segera dibuat, maka suami harus membuat keputusan yang dianggapnya paling baik dan dialah yang bertanggung jawab atas keputusan tersebut. Istri harus mengakui ketidaksetujuannya, tetapi harus menunjukkan kesediaan untuk bekerja bersama suami dan menerima kepemimpinan suaminya. Sikap semacam itu pada akhirnya akan membawa kesepakatan hati yang jauh lebih penting dari setiap masalah. Tindakan paling menyakitkan yang dilakukan seorang istri terhadap suaminya adalah dengan tidak memberikan tanggapan. ${ }^{9}$

\section{Instrumen Pengumpulan Data}

Dalam menganalisa Edukasi Pernikahan Masyarakat Kristen Dalam Pencegahan Perceraian, penulis melakukan dengan metode penyebaran angket kuisioner terhadap keluarga Kristen, untuk mengetahui pendapat mereka. Penelitian ini akan membagikan angket terhadap pasangan suami-istri dengan jumalh responden 50 keluarga. dari hasil pengumpulan data kuisioner yang disebarkan maka diperoleh hasil seperti dalam table dibawah ini:

Tabel 1: kompenen untuk menyusun pendapat Edukasi Masyarakat Kristen Dalam Pencegahan Perceraian.

\begin{tabular}{|l|l|c|c|}
\hline No & \multicolumn{1}{|c|}{ Pertaanyaan } & Ya & Tidak \\
\hline 1 & $\begin{array}{l}\text { Edukasi pernikahan sangat penting bagi calon pengantin } \\
\text { sebelum pemberkatan di gereja. }\end{array}$ & $\mathbf{4 7}$ & $\mathbf{3}$ \\
\hline 2 & Pernikahan memerlukan komunikasi yang baik & $\mathbf{4 4}$ & $\mathbf{6}$ \\
\hline 3 & Tuhan Pertama membangun lembaga pernikahan & $\mathbf{4 5}$ & $\mathbf{1 5}$ \\
\hline 4 & Tuhan sangat membenci perceraian & $\mathbf{5 0}$ & $\mathbf{0}$ \\
\hline 5 & $\begin{array}{l}\text { Pernikahan harus dipertahankan sampai maut yang } \\
\text { memisahkan. }\end{array}$ & $\mathbf{4 7}$ & $\mathbf{3}$ \\
\hline 6 & Pernikahan bukan semata-mata masalah seks & $\mathbf{5 0}$ & $\mathbf{0}$ \\
\hline 7 & $\begin{array}{l}\text { Orang Tua harus bertanggung jawab terhadap anak-anaknya } \\
\text { terhadap semua pasangan, baik pasangan muda maupun } \\
\text { pasangan yang sudah lama }\end{array}$ & $\mathbf{2 5}$ & $\mathbf{2 5}$ \\
\hline 9 & $\begin{array}{l}\text { Ekonomi salah satu penyebab masalah pertengkaran dalam } \\
\text { keluarga }\end{array}$ & $\mathbf{4 8}$ & $\mathbf{2}$ \\
\hline 10 & Setiap pasangan harus menjaga kekudusan pernikahannya. & \\
\hline
\end{tabular}

\section{Hasil Perhitungan Tabel 1.}

\footnotetext{
${ }^{8}$ gary Chapman, Dalam Pernikahan Yang Selamat Anda Dambakan (Ciputat: Gospel Press, 2007).

9 Evelyn Christenson, Penerapan Praktis Pola Hidup Kristen, (Tuhan Ubahlah Diriku) (Surabaya: Yayasan Gandum Mas, 1997).
} 


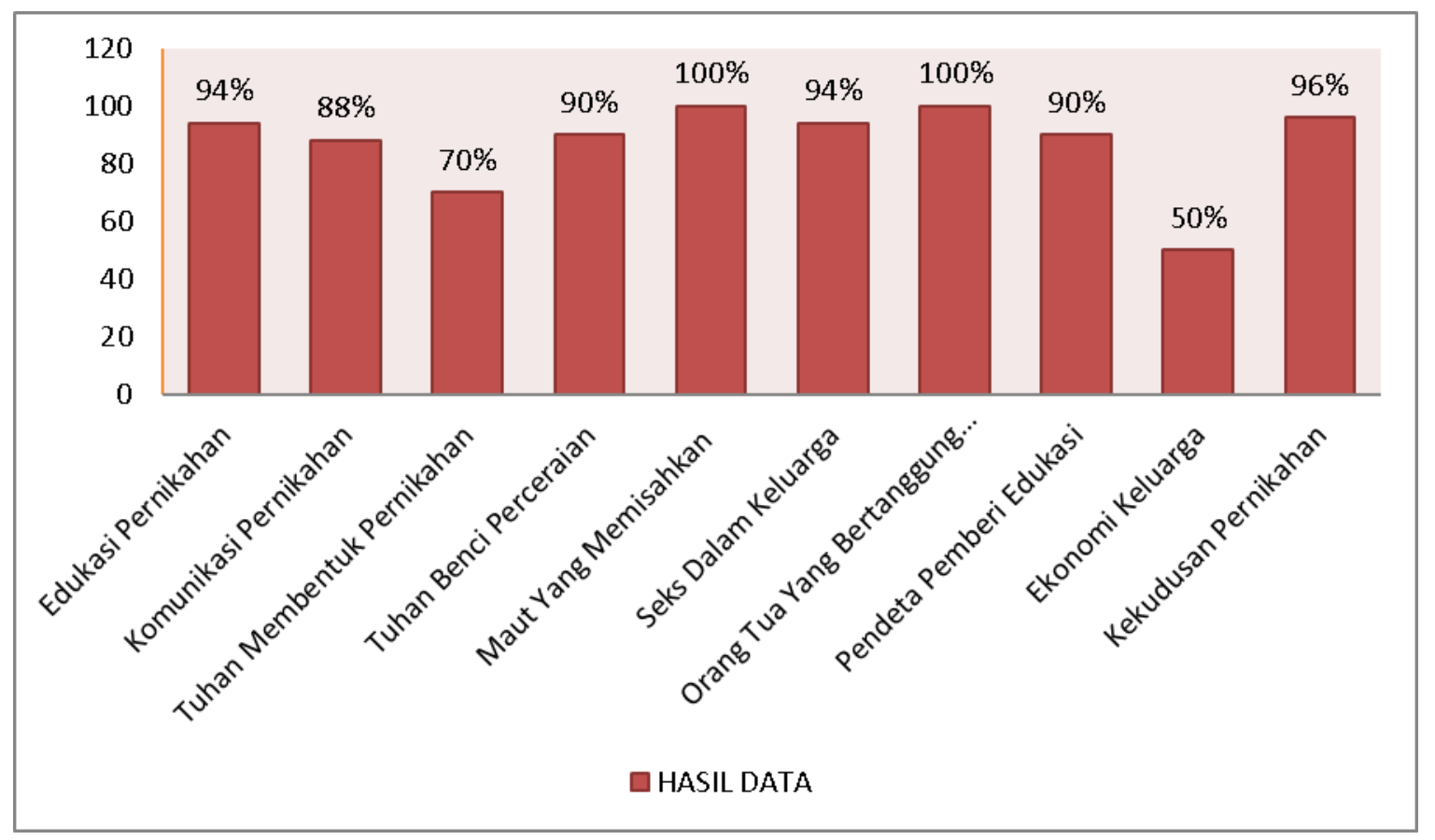

\section{SIMPULAN}

Menjadi seorang Kristen dan mencintai tidak cukup untuk suatu pernikahan yang berhasil. Banyak keluarga Kristen berakhir dengan perceraian, tetapi ribuan dan bahkan jutaan keluarga Kristen bertahan dalam pernikahan sampai maut memisahkan, mereka dapat menciptakan yang terbaik dalam pernikahan mereka. Pendidikan salah satu hal penting dalam kehidupan setiap manusia, gagalnya pendidikan juga merupakan kegagalan kehidupan dan masa depan. Edukasi pernikahan berbasis kebenaran Firman Tuhan, akan melahirkan konsep yang mutlak berbeda tentang pernikahan. Edukasi yang diberikan dengan prinsip-prinsip kebenaran Firman Tuhan tentang pernikahan dalam sudut pandang Alkitab yang diberikan oleh gereja/pendeta terhadap semua pasangan yang akan menikah, maupun yang sudah menikah akan membantu mereka dalam pencegahan perceraian. Pernikahan Kristen bukan hanya berbicara ekonomi, seks, mendidik anak, komunikasi serta tanggung jawab, melainkan esensi yang terbangun dari semula lembaga itu dibentuk oleh Allah yaitu Pernikahan harus diakhiri oleh kematian.

\section{DAFTAR PUSTAKA}

Berkhof, Louis, Cornelius Van Til. Foundations Of Christian Education. Surabaya: Momentum, 2008. Chapman, gary. Dalam Pernikahan Yang Selamat Anda Dambakan. Ciputat: Gospel Press, 2007. . Pernikahan Yang Selalu Anda Dambakan. tangerang: Gospel pres, 2007.

Christenson, Evelyn. Penerapan Praktis Pola Hidup Kristen, (Tuhan Ubahlah Diriku). Surabaya: Yayasan Gandum Mas, 1997.

Dobson, mames. "Pernikahan Dan Keluarga (Complete Marriage And Family. Gospel Press, Batam" (2005): 533.

Nick, Stinnet, Nancy joe, Beam Alice. Fantastic Families (Keluarga Kokoh Dan Bahagia). Batam centre: Interaksara, 2004.

Sugiono. Metode Penelitian Pendidikan, Pendekatan Kuantitatif, Kualitatif, Dan R\& D, Bandung, 2009.

Repulika.Co.Id. Pentingnya Edukasi Pranikah, Saturday, 30 Nov 2019., n.d. 